\title{
PROLOGUE
}

\section{War Is Not a Game}

"We're going over now. You ready?" a young veteran with a soul patch and a quicksilver smile asks a fellow vet who's grabbing a smoke outside the Holiday Inn in downtown St. Louis in August 2007. They exchange a short nod. The heat wave, close to one hundred degrees all week, has finally broken, so it's no longer punishing to venture beyond air conditioning. The two veterans, one lanky, the other solid as a door jamb, climb into a car, where a few others wait, and they all head down the street to the Missouri Black Expo job fair, now in full swing.

The exhibition hall is big, echoing, overlit, packed with job recruiters and seekers, but the clump of young men and women in black T-shirts with "Iraq Veterans Against the War" stenciled on the front is hard to miss as they make their way to the booth with "Go Army!" splayed across its canopy. A Humvee, decked out with fancy twenty-inch rims, is parked next to a table laden with brochures and sign-up sheets. There, military recruiters and civilian contractors chat with teens and encourage them to take turns playing "America's Army," a simulation game proclaiming itself to be "The Only Game Based on the Experience of Real U.S. Army Soldiers."

For the antiwar veterans, the buzz has begun the day before, when a handful of IVAW members are hanging around the hotel lobby on a break from the panel sessions at their third annual meeting. "There's a job fair going on across the street," someone says. "The army's got a recruiting booth, I saw them unloading a truck, we gotta do something." They bat ideas around until someone-probably Steve Mortillo or Jabbar Magruder-suggests a sound-off, and it clicks. The plan spreads with a quiet signaling among the veterans. Now, at the expo, they're ready for action.

"Fall in," comes the command, and the veterans do. Ninety people with real U.S. Army and Marine experience stand at attention in mass company 
formation four rows deep, their arms rigid at their sides. There's Camilo Mejia, the first soldier to be court-martialed for refusing to return to Iraq, and Kelly Dougherty, one of IVAW's founders and now its executive director. Liam Madden, who helped launch an Appeal for Redress to Congress and in three months got more than one thousand active-duty personnel to sign it, is there. Also Garett Reppenhagen, who co-hosted the first antiwar blog by an active-duty soldier, and Aaron Hughes, an artist-activist, who's about to spearhead IVAW's most ambitious project, the Winter Soldier investigation, which will offer grunt-level testimony about the wars next March.

Magruder takes his stance at the head of the formation and shouts, "Iraq veterans against the war, what have you learned?"

"War is not a game!" the veterans yell in unison.

Again comes the call and the response, "War is not a game."

Then a third exchange. And "War is not a game!" even louder now, caroms around the trusses of the ceiling.

Fernando Suarez, whose stepson, Jesus, had the dubious honor of being the first Mexican American to die in Iraq, stands in front, snapping photos and pumping his fist in the air, while the veterans applaud and cheer and high-five one another. As they disperse, a few police officers arrive. It's unclear who called them, but it doesn't matter. The veterans did their action, and they are stoked.

IVAW likes to talk about a "consent theory of power," in which the war in Iraq is depicted as an upside-down triangle balanced precariously on its tip and shored up by "pillars," including the military, the government, the education system, and public opinion. The goal is to topple the triangle by eroding the most vulnerable pillar, and that, the vets have decided, is support for the war among those who are fighting it. Today wasn't about theory, though. They saw an opportunity, they were nimble enough to seize it, they did something new, something big, and they didn't need anyone else to help them do it. "This is a new era of what action is and what protest is," announces Steve Mortillo, who served as an army cavalry scout near Samarra. It's evening now and he is introducing a video of the protest to the older veterans attending the Veterans For Peace annual convention. "With a small amount of people you can be so powerful to stop something like the U.S. recruiting machine in its tracks."

War Is Not a Game grew out of a feature I wrote for the Boston Globe in 2005, which grew out of the inquiry into resistance within the mili- 
tary that I had embarked on a couple of years earlier, when the invasion of Iraq seemed preordained. I had written about a small but prominent group of conscientious objectors in the First Gulf War, and I figured that if there was dissent in a volunteer military during that brief and surgical operation, there had to be something going on when a full-scale war, based on sketchier pretexts and prospects, loomed. With a mix of disbelief, anger, and despair, I watched my country tumble headlong into a war that seemed so pointless and wrong on so many levels-political, strategic, economic, moral-and as much as I like to be right, it only made it worse when all the dire predictions came to pass. But back at the beginning, what I needed was to look at the situation through other eyes, so I started talking with military counselors, soldiers about to be mobilized, soldiers gone AWOL, families caught in conflicting loyalties, and veterans groups. Somewhere along the way, I was hooked.

When Iraq Veterans Against the War emerged as a force in the antiwar movement, I realized that these veterans and active-duty solders were at the heart of the story I wanted to tell. I was intrigued by the paradox of warriors at the vanguard of an antiwar movement, attracted to their challenges to conventional pieties, moved that they had found a way to use their frustration, fury, and sorrow to try to force change, and, as always, curious about what propels people beyond bellyaching and onto the barricades. I liked their refusal to be reasonable, to shut up and behave as expected, especially the ones who no longer gave a damn about propriety, though the reason in too many cases-that the worst that could happen did-is hard to bear.

Yet, even as I watched the group evolve, I can't say exactly why these soldiers appealed to my very civilian soul. I'm not quite a pacifist, although my category of "just wars" is small; not quite a patriot, although I am plainly American and cherish much about my country; not quite antimilitary, although the closest I came to that world before I first reported on it twenty years ago was when the Russian army arrived at the front door to conscript my grandfather, who ran out the back door and didn't stop running until he got to America. And yet I am strongly drawn to these veterans.

Some of it is a shared weariness of perpetual war, some that I too am bored with chanting the same slogans over and over as Joan Baez, bless her ever-committed soul, warbles in the background-and making so little difference. These veterans may have exasperated and baffled me; 
they could be disorganized, defensive, insular, self-dramatizing, and impossible to get on the phone, but they were seldom boring. And although they were never more than a tiny portion of the military and never came close to stopping the army from doing what it wanted, they caused people in the army to stop and reconsider, and that changed many lives.

So maybe it comes down to this: There is a golden season in the life of a political movement when it is poised between obscurity and banality, inchoate impulse and ossified routine, a time so full of hope, so electric, it practically crackles. The poet Seamus Heaney wrote of a rare historical moment when "hope and history rhyme." For IVAW, that moment came early in 2007 and lasted for about eighteen glorious months. War Is Not a Game is the story of that time. 